\title{
With "frenemies" like these: rising power voting behavior in the UN General Assembly
}

Article

Accepted Version

Binder, M. ORCID: https://orcid.org/0000-0002-9144-3979 and Lockwood Payton, A. (2022) With "frenemies" like these: rising power voting behavior in the UN General Assembly. British Journal of Political Science, 52 (1). pp. 381-398. ISSN 14692112 doi: https://doi.org/10.1017/S0007123420000538 Available at https://centaur.reading.ac.uk/93690/

It is advisable to refer to the publisher's version if you intend to cite from the work. See Guidance on citing.

To link to this article DOI: http://dx.doi.org/10.1017/S0007123420000538

Publisher: Cambridge University Press

All outputs in CentAUR are protected by Intellectual Property Rights law, including copyright law. Copyright and IPR is retained by the creators or other copyright holders. Terms and conditions for use of this material are defined in the End User Agreement.

www.reading.ac.uk/centaur 
Central Archive at the University of Reading

Reading's research outputs online 

Assembly

\author{
Martin Binder \\ University of Reading \\ m.binder@reading.ac.uk \\ Autumn Lockwood Payton \\ University of Dayton \\ apayton1@udayton.edu
}

Total word count: 10,892

\begin{abstract}
The rise of non-Western powers has led to competing claims about how these states act amongst each other and how they behave vis-à-vis established powers. Existing accounts argue that the rising powers are a heterogenous group of competing states and that they are socialized into the existing Western-centered order. We challenge these claims, arguing that the rising powers are dissatisfied with the international status quo and that they have begun to form a bloc against the established powers. We contend that this dissatisfaction arises from their lack of influence on the international stage, their status in the international hierarchy, and the norms that sustain the current international order. We maintain that the formation of a rising powers bloc is driven by their economic growth and international dynamics, fostering their institutionalization as IBSA and BRICS. To support our argument, we combine spatial modeling techniques to analyze rising power voting behavior in the UN General Assembly over the period 1992-2011.
\end{abstract}

\title{
Acknowledgments
}

For helpful comments we thank the editor and three anonymous reviewers. We also thank Michael Bailey, Stephanie Hofmann, Anja Jetschke, Andrea Liese, Tom Long, Mareike Kleine, Eric Payton, Keith Poole, Sven Regel, Matthew Stephen and Bernhard Zangl. The data, replication instructions, and the data's codebook can be found at https://dx.doi.org/doi xxxxxx.

\section{Biographical statements}


MARTIN BINDER, PhD in Political Science (Free University Berlin, 2009); Associate Professor at the University of Reading (2015-); Main research interests: international organizations, international security. Recent publications in International Studies Quarterly, International Theory, and the Journal of Peace Research.

AUTUMN LOCKWOOD PAYTON, PhD in Political Science (Ohio State University, 2009); Lecturer in Political Science at the University of Dayton (2018-); Main research interests: international organizations, international political economy. Publications appearing in Review of International Organizations, International Studies Quarterly, and the Journal of Peace Research. 


\section{Introduction}

Since Thucydides' account of the Peloponnesian War, the rise of new powers and the resulting shifts in the international distribution of power have been associated with major turbulence in world politics. The current rise of non-Western powers such as Brazil, Russia, India, China and South Africa represents such a shift and is widely considered to be one of the most significant changes in international politics over the past few decades. ${ }^{1}$ While a growing body of literature has advanced our knowledge about the rising powers, we still lack a clear understanding of how the current power shift affects the international system. Do rising powers oppose established powers, creating potentially dangerous tension in international politics as some scholars and observers predict? Are we witnessing the “remaking of world order" (Acharya 2018; Huntington 1996; Kupchan 2012), or do we observe the integration and socialization of rising powers into the Western-centered international order, leading to harmony and cooperation between 'new' and 'old' powers, if not to the "ultimate ascendance of the liberal order" (Ikenberry 2011, 57; also, Kahler 2013), as others claim?

This paper challenges two prominent arguments: it questions the more optimistic view that the rising powers are socialized and integrated into the existing Western-centered order. It also counters the claim that these powers are a set of highly diverse actors with diverging if not competing interests and strategies (Hart and Jones 2010, Laïdi 2012). Rather, we

\footnotetext{
${ }^{1}$ Brazil, Russia, India, China and South Africa maintain key commonalities and have institutionalized as BRICS and IBSA Yet, we acknowledge important differences in their respective power, including those that are rising, though not (yet) major powers: Brazil, India and South Africa (according to the Correlates of War project or Volgy et al. 2011, 1-26 ); China, which has recently risen to major power status; and a former superpower in jeopardy of losing its major power status: Russia.
} 
argue that the rising powers have begun to form a bloc of dissatisfied states opposing the dominant Western powers and the status quo they maintain. We contend that this dissatisfaction arises from three sources: a) influence on the international stage, b) status in the international hierarchy and c) the norms and principles that sustain the current international order. Dissatisfaction with the international status quo is not new, but what has changed since the turn of the century is that the rising powers have begun to form a bloc of jointly dissatisfied states. The formation of this bloc, we argue, has resulted from endogenous and exogenous dynamics. Internally, the rising powers have experienced a contemporaneous increase in power over the past years driven mainly by unusually high economic growth rates - consistently higher than those in developed countries - enabling them to press for a more influential role in international politics. Externally, the limits of both Western self-restraint and capacity demonstrated by the war on terror after $9 / 11$, the war in Iraq without UN mandate, regime change in Libya and the instability of the 'liberal' order exemplified by the 2008 financial crisis have encouraged the formation of this bloc. Jointly, these dynamics have fostered the institutionalization of the rising powers as IBSA [India, Brazil, South Africa] and BRICS [Brazil, Russia, India, China, South Africa].

To evaluate whether the rising powers have begun to form such a bloc of dissatisfied states, we provide a systematic comparative analysis of rising powers and established powers across issue areas and over time. In doing so, we go beyond the extant scholarship on the rising powers that has favored anecdotal evidence including selected foreign policy episodes or statements of state leaders, or which has remained confined to the analysis of individual rising powers or of selected rising power-established power dyads (namely, the US and China). A smaller number of studies have examined the rising powers as a group, though these tend to focus on their inward dynamics, to the exclusion of their interaction 
with the established powers. Finally, many analyses remain confined to specific issue areas such as international climate negotiations or the international economy.

To address these limitations, our approach is to analyze the voting behavior of the rising powers within the context of a global multi-issue international organization (IO), the United Nations General Assembly (GA). Assessing voting in the GA is particularly wellsuited to address whether rising powers are forming a bloc and position themselves against established powers because it provides us with consistent data on the positions of a large number of countries (potentially all United Nations member states), both over time and across a broad range of issues in world politics. Our approach builds on work pioneered by Poole and Rosenthal (1991) to study voting in the US Congress and that scholars have extended to analyze voting behavior in international legislative bodies, such as the European Parliament (Hix 2001), the UN Human Rights Council (Hug and Lukács 2014) and the GA (Bailey et al. 2017; Voeten 2000; 2004). Particularly relevant to the present study is Voeten's (2000) analysis of voting in the GA, identifying the formation of a postCold War conflict line between Western and Non-western states. Voeten (2004) also finds support for the claim that the US has become an increasingly 'lonely superpower' in world politics. Two recent studies focus on rising powers using voting in the GA. Ferdinand (2014) seeks to identify the possible convergence in the foreign policies of BRICS states by comparing their voting behavior in the GA over six time periods between 1974 and 2011 to find increasing voting cohesion among them. Hooijmaaijers and Keukeleire (2016) examine whether the intensified interaction of the rising powers in the BRICS framework has resulted in stronger voting cohesion among the rising powers in the GA, over the period 2006-2014. Unlike Ferdinand, they conclude that it is "not possible to speak about a cohesive BRICS bloc in the General Assembly" (Hooijmaaijers and Keukeleire 2016, 397). These analyses remain largely restricted to voting cohesion among the rising powers and 
their findings are inconclusive. We go beyond these studies in two important ways. First, we analyze the voting behavior of rising powers both as a group and vis-à-vis the established powers. Second, we use methods that are better suited to shed light on voting behavior. Rather than relying on cohesion measures that are prone to bias - unable to discriminate between changes in preferences versus changes in the Assembly's agenda (Bailey et al. 2017, 433) - we use roll-call votes in the GA to construct probabilistic models of states' ideal points based on spatial models of voting, and assess how distant these are from one another. Specifically, we apply a combination of W-NOMINATE (Poole 2005) and a dynamic ordinal spatial model based on Item Response Theory (Bailey et al. 2017) to analyze more than 1,000 roll-call votes in the GA from 1992 to 2011, focusing on two different groups of rising powers (BRICS and IBSA). We compare their voting behavior to the coalition of major status quo powers representing the main supporters of 'liberal' world order - the G7, which has historically demonstrated a high degree of voting cohesion in the GA (Volgy et al 2003).

We find dramatic convergence in the voting behavior of the rising powers, largely in parallel to the institutionalization of BRICS and IBSA summits. Concurrently, our analysis reveals that the rising powers vote in ways that are fundamentally different from the established powers. In fact, the voting behavior of 'new' and 'old' powers differs across a large set of issues in international politics, ranging from human rights to disarmament, fault lines that have remained strikingly stable since the end of the Cold War. At a more general level, this suggests that international politics is characterized by a commonality of dissatisfaction $^{2}$ on the part of the rising powers and interest incompatibility between old

\footnotetext{
${ }^{2}$ We acknowledge helpful phrasing provided by an anonymous reviewer.
} 
and new powers rather than by the harmonious integration of the rising powers into the existing Western-centered international order.

The remainder of this article is structured as follows: In the next section, we develop our theoretical argument situated in four elements: sources of rising power dissatisfaction, internal economic growth, external dynamics, and the resulting institutionalization of the rising powers as a bloc of dissatisfied states (IBSA, BRICS). We then introduce the models of probabilistic voting and the GA voting data we use to test it. The penultimate section presents and interprets the results of the analysis. We conclude by briefly laying out some avenues for further research.

\section{Dissatisfaction and the formation of a counterhegemonic bloc}

We propose that the rising powers - Brazil, Russia, India, China and South Africa - are dissatisfied with the international status quo and have begun to form a bloc of states against the Western powers that maintain it. This argument builds on insights from power transition theory (PTT) that expects shifts in the international distribution of power to lead to turbulence and conflict in world politics (Kugler and Organski 1989; Organski 1968; Tammen et al. 2000). The main claim underlying this expectation is that powers experiencing a rapid relative increase in their economic, demographic, and military power are positioned to challenge the existing order that has been created by the dominant powers at the top of the international hierarchy to serve their interests. Conflict is likely to arise in such situations because the rising powers seek to change (or overthrow) the established order, while the dominant powers seek to resist substantial changes to that order, defending their privileged position therein. To some observers, conflict is almost inevitable during such power shifts (Gilpin 1983). For the proponents of PTT, by contrast, conflict does not 
follow automatically. It only occurs if the rising challenger is dissatisfied with the international status quo, that is, it is "dissatisfied with the established international leadership, its rules and norms, and wishes to change them" (Tammen et al. 2000, 9). While the scholarship on rising powers typically focuses on rising challenger/declining hegemon relationships (such as the US and China currently), PTT reminds us that dissatisfied rising powers can form partnerships to challenge the dominant power (Tammen et al. 2000, 11). At the same time, the rising powers do not necessarily confront a single hegemon but a group of established powers that together defend the international status quo (Wohlforth 1999, 30). In proposing that Brazil, Russia, India, China, and South Africa have begun to form such a bloc of dissatisfied states (as IBSA and BRICS) that oppose the 'liberal' international order and its main defenders, the US and its Western allies (the G7), our claim is that this dissatisfaction stems from three (interrelated) sources: dissatisfaction with (1) their influence in the current order, (2) with their status in that order, and (3) with the norms, rules, and institutions underpinning it.

Influence. Influence is the capacity of an actor to achieve desired outcomes by modifying a target's behavior and, while the means to achieving influence may be coercive, it may also be persuasive in nature (Knorr 1973). The rising powers all possess substantial economic, military, and political power resources (Hurrell 2006); however, they have not been able to fully transform these resources into political influence to secure material benefits and shape the international "rules of the game". Many Western-centered institutions maintain formal and informal rules that provide its most powerful (Western) members with disproportionate benefits and reflect those powers' normative understandings of international order (Ikenberry 2001). Rising powers have forcefully advocated, but with limited success, for reforms that would increase their influence in international institutions, including efforts to achieve UNSC reform, gain access to 
leadership positions in the WTO and the Inter-Development Bank, shape international negotiations on security, trade and climate change (Hopewell 2016; Narlikar 2011; Soares and Hirst 2006). Seeking greater influence in the Western-dominated Bretton Woods institutions, rising powers have demanded increases in their relative voting shares to counter a de facto G7 veto. And they have been critical of the informal procedure of appointing the head of the IMF and the Bank, where the Bank presidency is held by an American and the Fund's managing director is a European. ${ }^{3}$ But even when, in 2010, both institutions adapted to increase voting shares for the rising powers, the voting-power-toGDP ratio remained heavily skewed toward Western countries (Vestergaard and Wade 2015, 4-5). With the exception of Russia, the rising powers have also been excluded from G7/8 club of advanced industrial economies that was complemented, though not replaced, by the G20 group of developed and developing countries only in the context of the 2008 financial crisis. $^{4}$

Status. The rising powers also seek positive recognition or status (Deng 2008, 21). ${ }^{5}$ Like influence, status has material implications in that higher status can increase a state's power and wealth through enhanced economic and diplomatic exchange, but status also activates positive emotions like pride and respect. Domestically, leaders can generate legitimacy by credibly demonstrating a commitment to elevate the state's status (Ward 2017, 37). The rising powers believe they are entitled to a more important role in the Western-dominated international system (Hurrell 2006, 1-5), are all the dominant actors in their respective regions, and "have taken on a self-appointed role as leaders" (Stephen 2012, 293) in various

\footnotetext{
${ }^{3}$ Joint Statement of the BRIC Countries' Leaders, Yekaterinburg, Russia, June 16, 2009, para 3 http://www.brics.utoronto.ca/docs/090616-leaders.html

${ }^{4}$ On the level of the finance minsters the G20 has been meeting since 1999.

${ }^{5}$ See also Paul, et al. 2014, Renshon 2017; Volgy et al. 2011; Ward 2017.
} 
non-Western alliances, including the G77 at the UN and the G20 at the WTO. Their expectations have not yet been met by established powers, leading to status inconsistency or status dissatisfaction. Status elevation has been a key part of China's foreign policy since the mid-1990s (Deng 2008, 8-9), not least to generate domestic legitimacy for the Communist Party's leadership. India, too, has sought to elevate its international standing, mounting its own challenges to the existing order - most prominently by acquiring nuclear capability in violation of the non-proliferation regime (Nayar and Paul 2003, 11, 14-15). Similarly, Brazil and South Africa have demanded a permanent seat on the UN Security Council (Soares and Hirst 2006, 29; Schoeman 2015, 436). Unlike other rising powers, Russia is a resurgent power, often directing foreign policy pursuits at reestablishing its great power status and reasserting influence over the former Soviet states (MacFarlane 2006, 5). The G7/8 'outreach' (or Heiligendamm) process that began in the mid-2000s demonstrated a lack of recognition by the established powers, when Brazil, China, India, (and Mexico) were invited to join the G7/8 summits but were not included in decision making. Excluded from the main discussions, South African President Mbeki complained that the rising powers had "only been asked to join in the dessert and miss the main meal" (cited in Schoeman 2015, 435).

Normative dissatisfaction. The rising powers are not just unhappy about their lack of influence and status in the international order, they are also dissatisfied with the (Western) norms, rules, and institutions that underpin the existing order. Normative dissatisfaction results in efforts to change the normative foundation of the prevailing order (Ward 2017, 11). The post-Cold War era has seen a dramatic strengthening of Western norms that is at odds with those held by the rising powers: economic deregulation as reflected in the Washington Consensus versus interventionist state capitalism (Stephen 2014) and the promotion and protection of human rights and humanitarian intervention ("responsibility 
to protect") versus the primacy of state sovereignty (Hurrell 2006). With respect to international institutions, the rising powers have traditionally preferred unanimity decisions over majority decisions and sovereignty affirming international institutions over institutions with high levels of authority (Blake and Payton 2015).

Dissatisfaction with their influence, status, and prevailing international norms among rising powers is hardly new. What is novel and begs explanation is why these powers have begun to form a bloc of jointly dissatisfied states against the established Western powers. We argue that endogenous changes within the rising power group and exogenous dynamics that, taken together, have led to the institutionalization of the rising powers as IBSA and BRICS around the turn of the century.

Endogenous change. For a counterhegemonic bloc to form, not only must its members be dissatisfied with the international status quo, they must also rise in power which they achieve mainly through economic growth (Tammen et al. 2000, p. 17; Gilpin 1983). This applies to the rising powers that have experienced extraordinary economic growth rates since the early 2000s, empowering them to seek more diplomatic clout. Indeed, despite the economic woes of the new Russian Federation, the BRICS as a group, boasted higher economic growth rates than the G7 in the first decade after the fall of the Soviet Union (IMF 2019). The pace only quickened in the following decade, with the BRICS economies averaging just over 6\% growth, compared to the G7's 1.4\% (IMF 2019). Two widely noted reports published by Goldman Sachs in the early 2000s predicted a much greater weight of the BRICs in the world economy within the next decade (O’Neill 2001, 6-8) ${ }^{6}$ and projected

\footnotetext{
${ }^{6}$ The author of the 2001 report Jim O'Neill coined the term 'BRICs' (South Africa was not yet a member at the time)
} 
that the BRICs could overtake the US, Japan, UK, Germany, France and Italy in less than forty years (Wilson and Purushothaman 2003, 3-5). This shift represents a marked change in the international distribution of power and has been widely noted by scholars and observers. At the end of the 1990s Wohlforth argued that international politics was unambiguously and durably unipolar (1999, 7-8), with the US (and its Western allies) firmly on top of the international hierarchy. Just ten years later, observers noted that "the 'unipolar moment' is over" (Layne 2012, 203); that the US is "no longer a hyperpower towering over potential contenders;" and that the "rest of the world is catching up" (Schweller and Pu 2011, 41-42). Their rise in power has enabled the BRICS countries to press for more influential roles in world politics. For example, India, Brazil and South Africa strongly restated their traditional demands on international trade, the reform of international institutions, and economic development (Vieira and Alden 2011, 511). Brazil and India led the Group of 20 within the WTO developing countries, resisted attempts by the US and the EU to consolidate their agricultural subsidy policies; while China and Russia have prevented a meaningful UN response to the civil war in Syria, ${ }^{7}$ and, seeking to act as a global norm entrepreneur, Brazil has proposed "a responsibility while protecting" aimed at limiting the use of force included in the R2P's third pillar.

International dynamics. In addition to changes occurring within the rising powers, exogenous factors have helped to coalesce an otherwise heterogeneous group of states as the rise in power of Brazil, Russia, India, China and South Africa has coincided with a decline in the legitimacy and effectiveness of the Western-centered order. The aggressive unilateral security policies the US has adopted in its 'war on terror' after 9/11, the US-led

\footnotetext{
7 The fourth BRICS Summit: New Delhi Declaration 29 March 2012, para 21 http://www.brics.utoronto.ca/docs/120329-delhi-declaration.html
} 
2003 invasion of Iraq (without UN mandate), and regime change by Western powers in Libya in the name of the responsibility to protect, have damaged the legitimacy of the Western-centered order, and have exposed the limits of Western (and in particular US) strategic self-restraint (Pape 2005, 35; Mastanduno 2019; Schweller and Pu 2011; Walt 2006). In international trade, the dominant Western powers were unwilling at WTO Doha Round to open their markets for agricultural trade from the global South (Vieira and Alden 2012), and the $2007 / 8$ financial crisis has called to the attention of the rising powers the instability of 'liberal' economic and financial order, as well as the fiscal constraints facing the dominant Western economies (Armijio and Roberts 2014, 503).

Institutionalization. Both dynamics - endogenous change as well as external pressures and opportunities, we argue, have fostered the institutionalization of the rising powers as IBSA and BRIC(S) groups. Both groupings have multiple aims. They serve to increase intra-IBSA and BRICS cooperation, to harmonize their views across a set of international issues and to coordinate their foreign policies (Viera and Alden 2011, Armijio and Roberts 2014, Stuenkel 2015). The IBSA dialogue forum, established by India, Brazil and South Africa in 2003, had its first High Level meeting at the fringes of the G8 summit in Evian to serve as a tool for foreign policy coordination in the areas of international trade and security among the three countries (Vieira and Alden 2011). Like IBSA, BRICS is an informal institutional platform for cooperation and policy coordination. Initiated by Russia alongside the 2005 GA meeting, the BRICs members have been convening since 2006 (informally) and formally as BRICs since $2009 .{ }^{8}$ Apart from their respective annual summits, IBSA and BRICS have significantly intensified technical cooperation by developing a structure that mirrors the G-7 from finance and trade, to public health,

\footnotetext{
${ }^{8}$ South Africa entered the group in 2010/11.
} 
agriculture, science and research, the judiciary, and defense (Stuenkel 2015, chapter 5). But the BRICS also aim to challenge Western dominance in world politics and to increase their global influence by working together to harmonize their negotiation positions on a range of issues (Armijio and Roberts 2014, for IBSA see Alden and Viera 2012). According to one Brazilian representative, the BRICS serves its members as "a forum for convergence" (Stuenkel 2015, 89). Importantly, the BRICS have established parallel institutions such as the New Development Bank and the Contingency Reserve Agreement as an alternative to the IMF and the World Bank in which the dominant Western powers exercise disproportionate influence.

IBSA and BRICS members possess substantial economic, military, and political power resources, and differences persist. Yet, they have managed to leverage their diversity in advantageous ways. While China stands out as the most powerful among them, the other members help Beijing to multilateralize its foreign policy strategies, while bringing important resources to the table. Like China, Russia and India are nuclear powers. Moreover, Brazil and India can mobilize coalitions of developing states from the global South (Hopewell 2016). Russia, a resurgent power, offers unique know-how in dealing with the hegemon, while South Africa, a regional leader in Africa, adds legitimacy and representativeness to the club (Schoeman 2015, 434, 440-441). ${ }^{9}$

If our argument is correct and rising powers have begun to form a bloc of dissatisfied states, holding similar views about a range of international issues, we should observe an expression of their joint dissatisfaction with the international status quo by voting in

\footnotetext{
${ }^{9}$ South Africa has been admitted to the BRICs club despite Nigeria now being the continent's biggest economy (Schoeman 2015, 432).
} 
increasingly similar ways in the GA and by consistently voting against the US and its Western allies as the main defenders of that status quo. ${ }^{10}$

\section{Competing Views: The logic of integration}

Our argument challenges competing views on rising power behavior in important ways. First, it counters accounts depicting the rising powers as a set of highly diverse actors with diverging if not competing interests and strategies. It has been often argued, that the ability of the rising powers to oppose the Western powers is limited due to intra-BRICS rivalry. For example, Hart and Jones $(2010,85)$ note, "tensions within this group still outweigh tensions between any one member and the United States", while Laïdi (2012, 615) describes the BRICS as a "heterogeneous group of often competing countries" whose only commonality lies in a strong preference for state sovereignty and independence of national action.

Our argument also challenges accounts emphasizing processes of accommodation and socialization, which claim that rather than confronting the dominant powers, the rising powers integrate themselves harmoniously into the existing international order. Ikenberry, in particular, has extended the logic of liberal world order to the non-Western powers. In his view, the existing Western-centered order is expected to accommodate new powers rather than to give way to a more contested and fragmented system (Ikenberry 2011, also Kahler 2013). There are two mechanisms explaining integration. First, the existing order is harder to overturn - great power war is no longer a means to change the international

\footnotetext{
${ }^{10}$ We share Ball's view that a "bloc" is formed by states that consistently vote as a group on "all or particular kinds of issues" (Ball 1951:3).
} 
system, which makes change necessarily less radical and more incremental. Second, integration into the existing order is in the rising powers' own interest, as they benefit from its rules, practices and institutions (Ikenberry and Wright 2008, 11). Indicating that today's power shift is not the end of the 'liberal' order but represents its "ultimate ascendance" (Ikenberry 2011, 57).

Other make similar claims of a rather smooth integration by emerging powers, emphasizing processes of socialization. To the extent that rising powers participate in Western-shaped international institutions, socializing effects are expected to emerge through regular and sustained interaction in these institutions, altering the identities and ultimately the interests of their member states (Johnston 2008; Kent 2002).

Both claims bear observable implications for voting in the GA. If relations among the rising powers are characterized by political incoherence, tension, and disagreement, this should find its expression in divergent voting behavior of the IBSA and BRICS members in the GA. Likewise, voting in the GA should reflect the hypothesized processes of socialization. ${ }^{11}$ If an integrative logic of liberal world order is at work in international politics and the rising powers are being socialized into that order, we should observe interest convergence between rising powers (BRICS, IBSA) and the Western status quo powers (G7) in that they vote in (increasingly) similar ways in the GA. These predictions stand in contrast to the argument we offer, according to which we should observe that the

\footnotetext{
${ }^{11}$ Bearce and Bondanella (2007) have analyzed GA voting to find that membership in specific regional and global IOs involves processes of socialization, making member-state interests more similar over time.
} 
rising powers vote in similar ways among themselves and that they consistently vote against the established powers.

\section{Analyzing Voting in the UN General Assembly}

To empirically evaluate these propositions, we use GA roll-calls to construct probabilistic models of voting that rely on the assumptions of spatial models of politics; based in Black's (1958) median voter theorem. We use W-NOMINATE to estimate ideal points of UN member states. This allows us to assess the ideological distance among the rising powers (BRICS and IBSA states) and between the rising and established powers (the G7 states) in a multi-dimensional policy space (Poole et al. 2011; Reed et al. 2008; Voeten 2000). WNOMINATE facilitates the study of voting behavior because it allows us to identify the most salient cleavages upon which states vote-dimensionality of conflict-in international politics, and provides information about the content of votes in the GA (human rights, disarmament, economic development etc.); however, it is less suited to accommodate changes in the voting behavior over time (i.e. it is not dynamic). To address this potential problem, we complement the W-NOMINATE analysis with a (one-dimensional) dynamic model of voting based on item response theory (Bailey et al. 2017).

We believe that voting in the GA is appropriate to test our argument about rising power behavior in IOs. The GA is the "only forum in which a large number of states meet and vote on a regular basis on issues concerning the international community" (Voeten 2000, 186). This approach provides us with consistent data on the voting behavior of potentially all UN member states, across a large number of issues in international politics, and over a long period of time. 
We acknowledge that the analysis of voting in the GA carries some limitations. First, voting in the GA is largely symbolic; unlike resolutions in the Security Council, those adopted by the GA are non-binding. However, noncompulsory decisions and the lack of direct policy output lends states more freedom to maximize their interests than in other international arenas (Voeten 2000). Moreover, even though GA resolutions are not legally binding, they may nevertheless be consequential. As Abbott and Snidal indicate, inclusive institutions such as the GA "can have substantial impact on international politics by expressing shared values on issues like human rights [et cetera] in ways that legitimate or delegitimize state conduct" (Abbott and Snidal 1998, 24). Similarly, debates and voting within the GA are reflected in states' foreign policy behaviors such as loan disbursements by international financial institutions (Voeten 2012,3) and sanctions placed on Russia as a result of the annexation of Crimea. ${ }^{12}$

Second, some have suggested that voting in the GA is affected by vote buying - states trade votes in the GA for various forms of US aid (Dreher et al. 2008) or IMF loans (Dreher and Sturm 2012) - biasing the ways in which states vote. ${ }^{13}$ Others, however, have found that the extent of vote buying in the GA remains limited in scope (Carter and Stone 2015) and argue that the evidence concerning the conditions under which vote buying occurs is mixed (Mattes et al. 2015, 283). And, while vote buying may affect the voting behavior of weaker recipient states, this is less plausible when it comes to more powerful states such as the BRICS. If votes of the rising powers were 'bought', effectively pulling these states closer to the Western position, this would strengthen rather than undermine our argument, as we

\footnotetext{
${ }^{12}$ In the latter case, the G7 and the BRICS were on opposing sides of several resolutions (A/Res/71/205, A/Res/72/190, A/Res/73/194) with Brazil abstaining.

${ }^{13}$ Dreher, et al. 2008 find no evidence for vote buying on the part of the other G7 members.
} 
expect the rising powers to form a counterhegemonic bloc of states and to vote against the established Western powers. Thus, if vote-buying is occurring and we observe contestation, this means that in the unlikely case where rising powers submit to pressure to vote with the G7, they are resisting despite the carrots and sticks on offer.

To analyze the voting behavior of the rising powers in the GA we use the "United Nations General Assembly Voting data" compiled by Strezhnev and Voeten (2012). The data contains all roll-call votes; that is, all contested votes on resolutions in the GA. Resolutions that are not put to a vote because they were adopted "by consensus," "by acclamation," or similar measures are not included in the data set. These constitute the majority of the resolutions adopted in GA, around 64\% between 1974 and 2004 (Peterson 2006). We exclude resolutions without a vote for two reasons. First, they do not allow us to estimate the ideal points of rising and established powers. Second, the vast majority of resolutions that are adopted without a vote are inconsequential in that they do not require UN members to take specific actions. To this, add that a large proportion of resolutions call on the UN itself to act (to organize meetings or to coordinate with other intergovernmental organizations, for instance). As a result, the obligation to act often lies not with UN member states, but with the Secretariat and other UN bureaucracies. Only once this burden shifts to UN members themselves do we observe increased roll call voting. Specifically, roll call voting is almost always the modus operandi when states — or groups within states — are at the center of resolutions. The distinction is consistent with general knowledge about the political nature of the UN - once particular member states are implicated (or blamed), consensus falls by the wayside.

GA resolutions are adopted by a "one-state, one-vote" majority principle. The data report whether a state voted for or against the resolution, abstained from the vote, or was absent. 
Absenteeism is usually regarded as missing data. Abstentions, however, have been treated as missing values (Reed et al. 2008), or as intermediate action between "yea" and "nay" (Bailey et al. 2017). Here, we handle abstentions in two ways. First, we consider abstentions as another - softer - way of voting "no" and merge "abstentions" and "no" votes into the same category (Voeten 2000; 2004). This is because, in the GA, states use both types of votes to express disagreement with a resolution. As Voeten explains, "[S]ince UNGA resolutions are not binding, what really matters is whether or not a state is willing to go on the record for supporting a resolution." (Voeten 2000, 193). Second, we analyze a model in which abstentions are considered a mid-point.

We analyze two 10-year time periods, 1992-2001 and 2002-2011, spanning the immediate post-Cold War period through the post-9/11 period. The first period can be considered as "Western dominance" in world politics, following the dissolution of the Soviet bloc/Warsaw Pact. Additionally, this period includes South Africa's reinstatement of voting rights following the end of apartheid. ${ }^{14}$ The second period has been selected because it coincides with the rise in power of non-Western economies and their institutionalization as IBSA and BRICS.

Finally, we introduce the G7 as benchmark against which the formation of a rising power bloc and their confrontation of the dominant powers can be assessed. The G7 composes the world's major status quo powers, including the US, which makes it an appropriate touchstone. The G7 was formed in the mid-1970s by the most powerful liberal economies to address systemic disturbances and has since displayed consistently high levels of voting

\footnotetext{
${ }^{14}$ South Africa was suspended from the GA from 1974 to 1994.
} 
cohesion in the GA (Volgy et al. 2003, 105). ${ }^{15}$ The group has met as the G8 after the inclusion of Russia in 2002; however, they continue to meet more frequently sans Russia. Originally created as an informal institution to coordinate the world economy, the G7's tasks have expanded to a range of non-economic issues, including security and the environment. Overall, the G7 lends itself well as a comparison group because neither the G7 nor the IBSA and BRICS groups are caucusing groups whose voting behavior in the GA reflects prior formal compromise. Additionally, the IBSA and BRICS as well as the G7 are informal institutions or "clubs" and maintain a similar membership size.

\section{Probabilistic methods of voting: Two approaches}

In the following section, we discuss two different, yet complementary, approaches used to test our argument of counterbalancing by the rising powers against established powers and whether they register dissatisfaction with the status quo through contestation of the established Western-centered order. First, we use the W-NOMINATE estimation technique developed by Poole et al. (2011) to analyze all roll-call votes taken in the GA across the two time periods specified. Using the assumptions of spatial voting models (Black 1958; Downs 1957), the method estimates voters' ideal points, in this case, UN member states. States are assumed to maintain single-peaked preferences over an ideal choice in policy space, meaning possible options further from that choice are considered less desirable. In a one-dimensional model, each vote is represented by two points that correspond to the passage or failure of a resolution. States will either prefer the rejection or passage of a resolution based upon which is closest to their ideal point in Euclidean

\footnotetext{
15 The original 1975 forum included France, Germany, Italy, Japan, the United Kingdom, and the US, becoming the G7 after Canada was included in the following year.
} 
space. One advantage of W-NOMINATE is its ability to account for voter complexity, as preferences do not always accord with a single issue, or dimension. In multiple dimensions, the vote is a vector (with a given length and direction), and a state will have an ideal point associated with each dimension. Each roll-call vote is represented by a cutting line (or plane), which divides the yea from the nay votes. The proximity of a voter to a cutting line indicates the degree of confidence the model has in predicting whether a state will vote to accept or reject a resolution, where points that fall closer to the line reflect less certainty (Poole and Rosenthal 1991, 232). W-NOMINATE estimates the policy dimensions, the Euclidean distance from the location of the vote to the voter's ideal point, and the weight of the dimensions. When applied to domestic legislatures, the dimensions tend to reflect left-right or government-opposition divisions; however, domestic ideological cleavages rarely translate to the international arena. Whereas domestic legislatures or the EU Parliament (Hix 2001) lend themselves to a certain degree of predictability, the absence of established political parties in international politics leads to greater uncertainty over the nature of these dimensions in the GA. Despite these challenges, there are a number of techniques that can aid in the identification of dimensions as the international level.

W-NOMINATE is ideal for arenas in which groups are divided along more than one dimension, but it is not as adept in addressing the comparability of behavior over time. We therefore complement the analysis above with the method developed by Bailey et al. (2017). This technique is based on item response theory but shares many assumptions with W-NOMINATE. ${ }^{16}$ To allow for comparisons over time, the dynamic ordinal spatial model

\footnotetext{
${ }^{16}$ Spatial methods such as IRT and W-NOMINATE both use cut points, which divide votes along a spectrum, meaning that both preference changes and changes in the agenda can be taken into account.
} 
uses 'bridge observations' - resolutions in the GA that are identical over time - to identify whether changes in voting behavior are driven by a change in state preferences (Bailey et al. 2017, 435). Through the identification of these bridging votes, which isolate the cut points, shifting preferences may be ascertained from shifting parameters. However, this model is confined a single dimension and it treats abstentions as a midpoint between yes and no. We estimate the original IRT model as well as a modified version that categorizes nays and abstentions together to align it with the inputs of W-NOMINATE, allowing us to compare the findings from the W-NOMINATE analysis to the original and to our modified IRT models.

The analysis of ideal points allows us to assess two things. First, how cohesively rising powers - both BRICS and IBSA - and established powers act in the GA across the two time periods. The measure of cohesion is the average Euclidean distance between the members of each group to their respective centroid. ${ }^{17}$ Second, the magnitude between the ideal points of the rising powers and the G7 serves an indicator of convergence/divergence among the groups of states. To measure the magnitude between the two groups, we calculate the Euclidean distances between their centroids. The positions of these states in relation to the cutting lines are an indication of the degree of disagreement between the groups of states. Cohesion and distance scores are presented in Table 1 below.

\section{Results}

\section{Dimensionality of conflict}

\footnotetext{
Additionally, both methods are weighted. This prevents votes that diverge from the primary dimension of preferences from exacting undue influence on the estimates (Bailey et al. 2017, 433).

${ }^{17}$ Because the IRT models are one-dimensional the centroid is the arithmetic mean of the ideal points.
} 
The cohesion and distance of the BRICS and G7 groups are directly affected by the existence of multiple dimensions of voting. Thus, we briefly identify and discuss the salient dimensions before turning to the main results of the models. Further discussion of dimensionality may be found in the online appendix.

Figures 1(a) and 1(b) present the ideal point estimates for the first and second periods of study, respectively. Cutting lines represent four broad issue areas of GA voting: economic development, human rights, nuclear proliferation and Israel/Palestine. The angles and positions of the cutting lines offer indications for the nature of the dimensions. Specifically, cutting lines with angles between 70 and 110 degrees fall within the first dimension, while angles of 0-30 degrees or 150-180 degrees fall within the second dimension. Lines that fall in the intermediate ranges occur in both dimensions (Voeten 2000).

The median cutting lines of each issue area indicate a "West v. Rest" division, echoing Voeten's (2000) findings. Issues of economic development, human rights and nuclear proliferation — with respective angles of 96,101 and 82 degrees in the final period — present a clear divide between Western countries and most of the rest of the world. The angle for the Palestinian question, particularly from 2002-2011, falls well outside the exclusive first dimension (135 degrees) and even divides the U.S. and Canada from the rest of the G7. Figure 1, including the proximity of U.S. and Israeli ideal points in both periods (virtually stacked on top of each other), suggest a second dimension that is based on a pro/anti-Israel policy position. Having addressed the probable nature of two dimensions along which GA voting is structured, we now turn to the results of the two probabilistic methods of voting to determine whether the rising powers act as a bloc in the GA and the extent to which they vote with or against the status quo powers. 

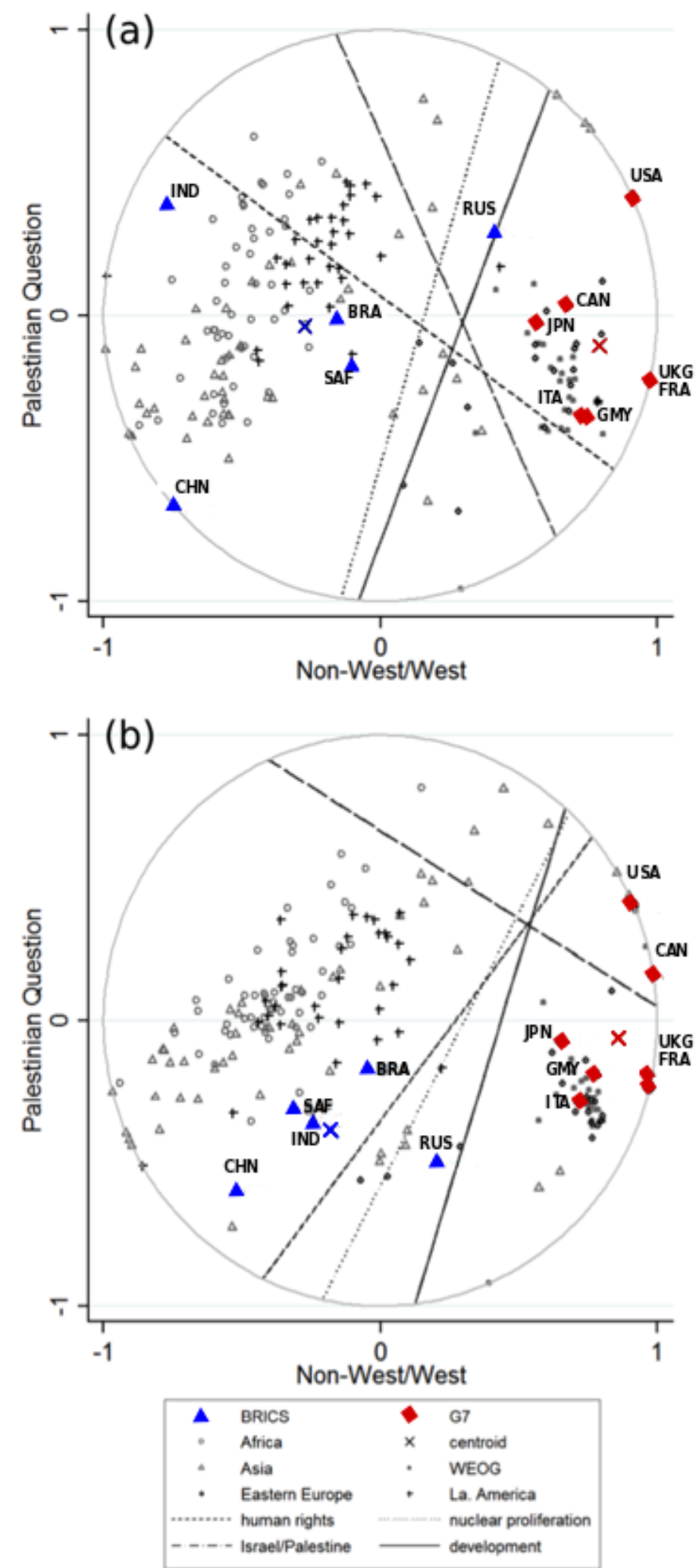

Figure 1: (a) Spatial map 1992-2001 period with ideal points and group centroids. (b) Spatial map 2002-2011 period with ideal points and group centroids.

Rising power bloc formation 
Table 1 reports the findings of the three models- (1) W-NOMINATE, (2) IRT where abstentions are a mid-point between yea and nay and (3) IRT where abstentions are treated as nays. These findings lend strong support to our argument that the rising powers have begun to form a bloc of dissatisfied powers in the GA. As visual inspection of Figure 1 and the dispersion scores reported in Table 1 suggest, the rising powers have coalesced over the two periods. Models 1 and 2 indicate that the IBSA and BRICS countries maintained larger dispersion scores than the G7 group in the first post-Cold War decade (with the exception of IRT model (3)). The BRICS were highly dispersed with China and India far removed from the group centroid and Russia positioned closer to the G7 camp than to the other emerging powers. Three cutting lines in Figure 1(a) - nuclear proliferation, the Palestinian question and human rights divide China, India, Brazil and South Africa from Russia (and the G7 members), indicating substantial disagreement among the rising powers over these issues. Russia's closer position to the Western camp in the GA captures the democratization period of Russian politics, when the country adopted a more open stance towards the West, joining the G8 as well as the Council of Europe. While the cutting lines and distance from the $\mathrm{G} 7$ reveal a general dissatisfaction with the status quo powers on the part of the rising powers, there is little to suggest that they were acting in concert to oppose the $\mathrm{G} 7$ position.

Unlike the rising powers, the G7 group displays lower dispersion scores during the period 1992-2001 in models 1 and 2, indicating that the status quo powers formed a cohesive group in the GA. As Figure 1 demonstrates, the G7 members also found themselves on the same side of all four cutting lines, indicating a high level of agreement across these issue areas. As the positions of cutting lines illustrate, the G7 countries were frequently in the minority. This is consistent with the view that the GA is a forum in which the Western powers are frequently outvoted by developing countries. 
In the second, post-Cold War, decade (2002-2011), the picture changes quite dramatically, as we observe significant convergence in the voting behavior among the rising powers. This convergence coincides with their institutionalization as BRICS and IBSA in the past decade. In fact, as their lower dispersion score reveals, the BRICS now vote nearly as (model 1) or more (models 2 and 3) cohesively than the G7 bloc (Table 1). This finding is consistent with the argument of a jointly dissatisfied bloc of rising powers.

Even more striking is the percentage change in the dispersion score amongst the BRICS, IBSA, and G7 groups. Dispersion amongst the BRICS countries has contracted considerably, from $49 \%$ in model 1 to $77 \%$ in model 3 . Compare this with the G7, which has also experienced a relative decline in dispersion over the two decades, but the change is much less dramatic, ranging from $4 \%$ to $11 \%$. The changes in IBSA across the two periods have tracked more closely with the BRICS. Thus, the degree of change amongst the BRICS and IBSA groups is far more substantial than that of the G7.

At the same time, there is some variation within the camps of emerging powers. While Russia has moved away from the West and closer to the rest of the rising powers, it remains on the opposite side of the nuclear proliferation and human rights median cutting lines compared to the remaining rising powers (Figure 1(b)). This offers some support for arguments that Russia, while it clearly has moved closer to the rising power bloc, is a special case within this group (Hart and Jones 2010, 67; MacFarlane 2006). Finally, in the second period, IBSA dispersion scores are lower than those of the G7 and BRICS in models 1 and 2. This would be consistent with arguments that the IBSA states - democratic countries from the global South - maintain common positions in global affairs and may 
even share a sense of collective identity (Antkiewicz and Cooper 2011, 303). ${ }^{18}$ It is also consistent with the findings of Mielniczuk's (2013) study according to which the rising powers have formed a discursive bloc in the GA to employ common public rhetoric that centers on notions of multipolarity, non-intervention, poverty alleviation and the restructuring of international institutions (1087).

Turning to the G7, we find that these states continue to display a high level of voting cohesion, indicated by their low dispersion scores in the second period. As the cutting lines in Figure 1 (b) demonstrate, the US and Canada (and a few small island states) vote with Israel, while the other members of the G7 vote with the large majority of the UN member states. Moreover, we observe a widening gap between the US and the other G7 members, a result that we can observe both visually and in terms of the ideal points across all models. This offers support for the argument that the US, while clearly in the Western 'camp' in the GA, has become a rather 'lonely' superpower (Voeten 2004).

Overall, both methods - W-NOMINATE and IRT - indicate voting convergence among the rising powers, lending strong support to our argument that, despite their differences, the rising powers have begun to form a bloc in the second period under investigation that was characterized by the accelerated economic growth within the rising power camp, a change in the international dynamics (decline of Western self-restraint and effectiveness), and the institutionalization of the rising powers as IBSA and BRICS.

\footnotetext{
${ }^{18}$ Looking distribution of identities among great powers Allan et al. (2018) do not find evidence for a distinct identity shared by the rising powers.
} 
Table 1: Measures of dispersion and distance in GA voting models

\begin{tabular}{|c|c|c|c|c|c|c|c|c|c|}
\hline & \multicolumn{3}{|c|}{$\begin{array}{c}\text { Model 1 } \\
\text { W-NOMINATE }\end{array}$} & \multicolumn{3}{|c|}{$\begin{array}{c}\text { Model 2 } \\
\text { IRT- Abstentions as nays }^{\dagger}\end{array}$} & \multicolumn{3}{|c|}{$\begin{array}{c}\text { Model 3 } \\
\text { IRT-Abstentions as midpoint }^{\dagger \dagger}\end{array}$} \\
\hline & $1992-2001$ & $2002-2011$ & $\begin{array}{l}\% \\
\text { change }\end{array}$ & $\begin{array}{l}1992- \\
2001\end{array}$ & $\begin{array}{l}2002- \\
2011\end{array}$ & $\begin{array}{l}\% \\
\text { change }\end{array}$ & $1992-2001$ & 2002-2011 & $\begin{array}{l}\% \\
\text { change }\end{array}$ \\
\hline \multicolumn{10}{|l|}{ Dispersion } \\
\hline BRICS & 0.509 & 0.257 & $-49.51 \%$ & 0.543 & 0.208 & $-61.69 \%$ & 0.114 & 0.026 & $-77.19 \%$ \\
\hline IBSA & 0.362 & 0.131 & $-63.81 \%$ & 0.395 & 0.095 & $-75.95 \%$ & 0.088 & 0.056 & $-36.36 \%$ \\
\hline G7 & 0.273 & 0.248 & $-9.16 \%$ & 0.464 & 0.444 & $-4.34 \%$ & 0.376 & 0.334 & $-11.17 \%$ \\
\hline \multicolumn{10}{|l|}{ Distance } \\
\hline BRICS-G7 & 1.067 & 1.090 & $+2.16 \%$ & 1.898 & 1.772 & $-6.64 \%$ & 0.921 & 0.911 & $-1.09 \%$ \\
\hline IBSA-G7 & 1.149 & 1.079 & $-6.09 \%$ & 2.014 & 1.783 & $-11.47 \%$ & 0.986 & 0.940 & $-4.67 \%$ \\
\hline$\mu$ distance & 0.760 & 0.746 & $-1.8 \%$ & 0.883 & 0.893 & $+1.02 \%$ & 0.366 & 0.349 & $-4.64 \%$ \\
\hline
\end{tabular}

Notes: Dispersion is the average of the absolute values of the distance from the centroid. " $\mu$ distance" is the average distance between any two ideal points in the GA.

"Ideal point values between [-1, 1].

Ideal point values between [-1.47, 1.67].

${ }^{\dagger}$ Ideal point values between [-1.90, 3.01]. 


\section{Distances between the two blocs}

Having established the degree of in-group cohesion, we turn to how the rising powers position themselves vis-à-vis the established powers. Do they vote against the dominant Western powers, as our argument suggests, or do we rather observe convergence in the voting behavior of rising and established powers, suggesting that processes of socialization and integration are at work? To answer this question, we examine the Euclidean distances between centroids of the BRICS and IBSA states and the G7.

The position of the groups in relation to the cutting lines in Figure 1(b) and the distance scores reported in Table 1 support the proposition that the rising powers - with the partial exception of Russia - are dissatisfied, disagreeing with the established powers over key issues international politics. Not only do both BRICS and IBSA members frequently vote against the G7 countries, the distances between the two camps are also large - well above the average distance between any two members of the GA for that period (as shown in the final row of Table 1, " $\mu$ distance"). Across all models, the distance between the BRICS and the $\mathrm{G} 7$ is around $50 \%$ greater than the average distance and, in some cases, it is nearly 2.5 times larger (models 2 and 3). ${ }^{19}$ The difference between the groups is even more striking in both of the IRT models (2 and 3), where the distances between the G7 and BRICS fall within the $95^{\text {th }}$ percentile. The extent of disagreement between rising and established powers becomes even clearer when we compare the scores in Table 1 to other meaningful distances between two ideal points. Using distance scores from model 1 , we know, for instance, that the US and Israel are close allies and have very similar foreign

\footnotetext{
${ }^{19}$ W-NOMINATE plots the ideal points on a scale ranging from -1 to 1 on both dimensions. Hence, the maximum theoretical Euclidean distance that one member of the GA can be from another is 2; the minimum distance is 0 .
} 
policy preferences, which is reflected in an average distance between their ideal points of 0.02. Likewise, the distance between the two EU members, Germany and France, is 0.19 . Whereas, the distance between the US and North Korea is 1.99 , meaning that the two countries are almost always opposed in the GA.

While our results show that the distance between both groups is large, and that new and old powers disagree substantially over important issues in international politics, we also find that the distances between the BRICS and IBSA states and the G7 have remained fairly stable over time. There has not been a marked shift in the sense of a convergence of their voting behavior, nor do our results suggest that the two groups have drifted further apart. This is in spite of increasing participation of the rising powers in international organizations. From 1992-2011 shared memberships in intergovernmental organizations for the BRICS countries increased by $11.4 \% .{ }^{20}$ However, increased shared memberships with established powers, has not led to socialization nor interest convergence on the part of the rising powers. What our data does reveal is a relatively persistent chasm between these two groups of states despite more opportunities for socialization. While this division is not new, what has changed is that the rising powers have become much more powerful, to a point where they are considered as 'systemically important' in that major international problems such as financial crises can no longer be addressed without them (Payne 2014, 1).

The large Euclidean distance between the two camps, their location on different sides of the various cutting lines, and the significant convergence in the voting of the rising powers

\footnotetext{
${ }^{20}$ Using the Correlates of War Intergovernmental Organizations Data (Pevehouse, et al. 2004), we assessed BRICS shared memberships in over 300 IGOs.
} 
during the past decade, together offer strong support to our argument that the rising powers form partnerships in which the dissatisfied states align in opposition to the status-quo coalition.

These findings — rising power cohesion has increased significantly and the distance between them and the G7 is large and relatively stable over time - contradict the widelyheld view that the rising powers form a heterogeneous group of competing countries, and they challenge theories of accommodation and socialization, which would predict interest convergence over time (Bearce and Bondanella 2007). What our results clearly show is that there is no evidence for an alignment of interests between new and old powers. Contrary to Ikenberry's claim, we observe the persistence of a "contested and fragmented system of blocs" rather than an "ultimate ascendance" of a liberal global order, at least when we consider the voting behavior of rising and established powers in the UN General Assembly (Ikenberry 2011, 56-57).

\section{Conclusion}

Few observers dispute that the current power shift is real. What is much more contentious is whether the rising powers are dissatisfied with the international status quo and whether they act as a bloc. To help answer this key question in world politics, this paper proposes an argument for assessing the degree of dissatisfaction among rising powers and whether that dissatisfaction is reflected through the formation of a counterhegemonic bloc within the context of the GA.

We contribute to this research program by advancing an argument of rising power dissatisfaction highlighting three important motivations - the quest for influence, status, 
and their objection to prevailing norms that have come to dominate multilateral institutions like the United Nations. These motivations combine with endogenous factors, changing international dynamics, and their institutionalization on the basis of their shared dissatisfaction.

Methodologically, we contribute to the systematic analysis of rising power behavior by testing these propositions through spatial modeling techniques, analyzing rising power behavior in the GA across a range of issue areas and over time. We find notable convergence among rising powers, demonstrated by substantial tightening of the policy space among them. Thus, the rising powers are now considered to be system relevant and their voting behavior suggests a commonality of dissatisfaction with the international status quo. Moreover, the results reveal persistent disagreement between old and new powers and are at odds with arguments that predict their harmonious integration into the 'liberal' world order. Rather, their behavior within international fora such as the UNSC where they worked together to block a meaningful response to the war in Syria, or their individual foreign policies outside IOs, such as Russia's annexation of Crimea or China's "one-belt-one-road" project suggest that the rising powers have become more assertive.

We have focused on one particular forum, the GA, in which rising powers share membership with established powers; however, shared IOs are clearly not the only arenas in which rising powers can challenge the international status quo. Our argument of contestation as a group of dissatisfied states also applies to new organizations that exclude established powers, such as the New Development Bank and the Shanghai Cooperation Organisation, as well as continued coordination through informal institutions like the G20. Future research should analyze rising power behavior in these institutions in comparable 
ways to understand the scope and depth of the dynamics of bloc formation and contestation as well as their implications for institutional reform (Zangl et al. 2016).

Another avenue for future research is to investigate to what extent the rising powers engage in active coordination to counter the established powers. In the context of GA voting, our data cannot directly address this question, however, as states typically negotiate behind closed doors. Observers have noted that the BRICS "are holding regular meetings of their permanent representatives of the UN in New York and Geneva to coordinate policies" (Armijio and Roberts 2014, 505), but they also point out that a difficulty for research on BRICS foreign policy interaction is that the BRICS make available little or no information about the actual outcomes of these various interactions (Hoojimaaijers and Keukeleire 2016, 393).

However, scholars and practitioners suggest that the BRICS and IBSA states coordinate in other institutions and fora. In the context of the WTO, Hopewell finds that "Brazil, India and China exhibited a remarkable degree of collaboration. Aligning themselves with one another to counter the traditional powers, the emerging powers were highly successful in accommodating their differences, coordinating their positions wherever possible, and managing inevitable tensions within their relationship" $(2017,1369)$. With regard to the BRICS, Desai concludes that "[n]ot since the days of the Non-Aligned Movement and its demand for a New International Economic Order in the 1970s has the world seen such a co-ordinated challenge to western supremacy in the world economy from developing countries," while a senior Obama administration official stated that it was "remarkable how closely coordinated [Brazil, South Africa, India, China] have become in international 
fora, taking turns to impede US/EU initiatives" (cited in Wade 2011, 347). Whether rising powers coordinate their foreign policies at the UN deserves more scholarly attention.

For all the discussion of new versus enduring global orders, there is little consensus among scholars and practitioners of international relations on what to call the current global moment and its corresponding power distribution. While the present era of international politics still searches for a name, there is little doubt that some countries that have remained outside the main power dynamic are searching for a way into the club of 'rule-makers'. 


\section{References}

Abbott KW and Snidal D (1998) Why states act through formal international organizations. Journal of Conflict Resolution 42(1), 3-32.

Acharya A (2018) The End of American World Order. Cambridge: Polity Press.

Allan, B, Vucetic, S, Hopf, T (2018). The distribution of identity and the future of international order: China's hegemonic prospects. International Organization, 72(4), 839-869.

Antkiewicz A and Cooper AF (2011) Beyond geography: BRIC/SAM and the new contours of regionalism. In Shaw TM, Grant AJ, Cornelissen S (eds), The Ashgate Research Companion to Regionalisms. Burlington, VT: Ashgate, pp. 295-309.

Armijo L and Roberts C (2014) The emerging powers and global governance: why the BRICS matter. In Looney R (ed), Handbook of Emerging Economies. New York: Routledge, pp. 503-524.

Bailey MA, Strezhnev A, Voeten E (2017) Estimating dynamic state preferences from United Nations voting data. Journal of Conflict Resolution 61(2), 430-456.

Ball, MM (1951) Bloc voting in the General Assembly. International Organization 5(1), $3-31$.

Bearce DH and Bondanella S (2007) Intergovernmental organizations, socialization, and member-state interest convergence. International Organization 61(4), 703-33.

Black D (1958) The Theory of Committees and Elections. Cambridge: Cambridge University Press. 
Blake DJ and Lockwood Payton A (2015) Balancing design objectives: analyzing new data on voting rules in intergovernmental organizations. The Review of International Organizations 10(3), 377-402.

Carter DB and Stone RW (2015) Democracy and multilateralism: the case of vote buying in the UN General Assembly. International Organization 69(1), 1-33.

Deng Y (2008) China's Struggle for Status: The Realignment of International Relations. Cambridge: Cambridge University Press.

Desai, R (2 April 2013) Bloc Voting in the General Assembly The Guardian, Retrieved from https://www.theguardian.com/commentisfree/2013/apr/02/brics-challengewestern-supremacy.

Downs A (1957) An Economic Theory of Democracy. New York: Harper \& Row.

Dreher A, Nunnenkamp P, Thiele R (2008) Does US aid buy UN General Assembly votes? A disaggregated analysis. Public Choice 136(1-2), 139-164.

Dreher A and Sturm, JE (2012) Do the IMF and the World Bank influence voting in the UN General Assembly? Public Choice 151(1-2), 363-397.

Ferdinand P (2014) Rising powers at the UN: an analysis of the voting behaviour of BRICS in the General Assembly. Third World Quarterly 35(3), 376-391.

Gilpin R (1983) War and Change in World Politics. Cambridge: Cambridge University Press.

Hart AF and Bruce DJ (2010) How do rising powers rise? Survival 52(6), 63-88.

Hooijmaaijers B and Keukeleire K (2016) Voting cohesion of the BRICS countries in the UN General Assembly, 2006-2014: A BRICS too far? Global Governance 22(3), 389407. 
Hix S (2001) Legislative behaviour and party competition in the European Parliament: an application of Nominate to the EU. Journal of Common Market Studies 39(4), 663-88.

Hopewell K (2016) Breaking the WTO: How Emerging Powers Disrupted the Neoliberal Project. Stanford: Stanford University Press.

(2017) The BRICS - merely a fable? Emerging power alliances in global trade governance. International Affairs 93(6), 1377-1396.

Hug S and Lukács R (2014) Preferences or blocs? Voting in the United Nations human rights council. The Review of International Organizations 9(1), 83-106.

Huntington SP (1996) The Clash of Civilizations and the Remaking of World Order. New York: Simon and Schuster.

Hurrell A (2006) Hegemony, liberalism and global order: what space for would-be great powers? International Affairs 82(1), 1-19.

Ikenberry JG (2001) After Victory: Institutions, Strategic Restraint, and the Rebuilding of Order after Major Wars. Princeton: Princeton University Press.

(2011) The future of the liberal world order. Internationalism after America. Foreign Affairs 90(3): 56-68.

Ikenberry JG and Wright T (2008) Rising Powers and Global Institutions. A Century Foundation Report. Available from:

http://www.tcf.org/publications/internationalaffairs/ikenberry.pdf.

International Monetary Fund. 2019. World Economic Outlook (April 2019). Available from: https://www.imf.org/external/datamapper/datasets/WEO.

Johnston AI (2008) Social States: China in International Institutions, 1980 - 2000. Princeton: Princeton University Press. 
Kahler M (2013) Rising powers and global governance: negotiating change in a resilient status quo. International Affairs 89(3), 711-29.

Kent A (2002) China's international socialization: the role of international organizations. Global Governance 8(3), 343-64.

Knorr, K (1973) Power and Wealth: The Political Economy of International Power. New York: Basic Books.

Kugler J and Organski AF (1989) The power transition: a retrospective and prospective evaluation. In Midlarsky MI (ed), Handbook of War Studies. Boston: Unwin Hyman, pp. $171-94$.

Kupchan CA (2012) No One's World: The West, the Rising Rest, and the Coming Global Turn. Oxford: Oxford University Press.

Laïdi Z (2012) BRICS: Sovereignty power and weakness. International Politics 49(5), $614-32$.

Layne C (2012) This time it's real: the end of unipolarity and the Pax Americana. International Studies Quarterly 56(1), 203-213.

MacFarlane NS (2006) The 'R' in BRICs: is Russia an emerging power? International Affairs 82(1), 41-57.

Mastanduno M (2019) Liberal hegemony, international order, and US foreign policy: A reconsideration. The British Journal of Politics and International Relations 21(1), 4754.

Mattes M, Leeds BA, Carroll R (2015) Leadership turnover and foreign policy change: societal interests, domestic institutions, and voting in the United Nations. International Studies Quarterly 59(2), 280-290. 
Mielniczuk F (2013) BRICS in the contemporary world: changing identities, converging interests. Third World Quarterly 34(6), 1075-1090.

Narlikar A (2011) Is India a responsible great power? Third World Quarterly 32(9), 16071621.

Nayar BR and Paul TV (2003) India in the World Order: Searching for Major-Power Status. Cambridge: Cambridge University Press.

O'Neill J (2001) Building better global economic BRICs. Goldman Sachs Global Economics Paper 66.

Organski AF (1968) World Politics $2^{\text {nd }}$ Ed. New York, NY: Knopf.

Pape RA (2005) Soft balancing against the United States. International Security 30(1), 7 45.

Paul TV, Larson DW, Wohlforth WC (2014) Status in World Politics. Cambridge: Cambridge University Press.

Payne T (2014) The Global Governance of Global Crisis: Why the G20 Summit was Created and What We Still Need it to Do. University of Sheffield SPERI Working Paper.

Peterson MJ (2006) The UN General Assembly. London: Routledge.

Pevehouse JC, Nordstrom T, Warnke K (2004) The COW-2 international organizations dataset version 2.0. Conflict Management and Peace Science 21(2), 101119.

Poole KT (2005) Spatial Models of Parliamentary Voting. Cambridge: Cambridge University Press.

Poole KT and Rosenthal H (1991) Patterns of congressional voting. American Journal of Political Science 35(1), 228-78. 
Poole KT, Lewis J, Lo J, Carroll R (2011) Scaling roll call votes with nominate in R. Journal of Statistical Software 42(14), 1-21.

Reed W, Clark DH, Nordstrom T, Hwang W (2008) War, power, and bargaining. The Journal of Politics 70(4), 1203-16.

Renshon J (2017) Fighting for Status: Hierarchy and Conflict in World Politics. Princeton: Princeton University Press.

Schoeman M (2015) South Africa as an emerging power: from label to 'status consistency'? South African Journal of International Affairs 22(4), 429-445.

Schweller RL and Pu X (2011) After unipolarity: China's visions of international order in an era of U.S. decline. International Security 36(1), 41-72.

Soares de Lima MR and Hirst M (2006) Brazil as an intermediate state and regional power: action, choice and responsibilities. International Affairs 82(1), 21-40.

Stephen MD (2012) Rising regional powers and international institutions: The foreign policy orientations of India, Brazil and South Africa. Global Society 26(3), 289-309.

(2014) Rising powers, global capitalism and liberal global governance: A historical materialist account of the BRICs challenge. European Journal of International Relations 20(4), 912-938.

Strezhnev A and Voeten E (2012) United Nations General Assembly Voting Data. Version 4. Available from http:/hdl.handle.net/1902.1/12379 UNF:5:s7mORKL1ZZ6/P3AR5Fokkw==.

Stuenkel O (2015) The BRICS and the Future of Global Order. Lanham, MD. Lexington Books. 
Tammen RL, Kugler J, Lemke D, Alsharabati C, Efird B, Organski AF (2000) Power Transitions: Strategies for the 21st Century. New York: Chatham House.

Vestergaard J and Wade RH (2015) Still in the woods: Gridlock in the IMF and the World Bank puts multilateralism at risk. Global Policy 6(1), 1-12.

Vieira MA and Alden C (2011) India, Brazil, and South Africa (IBSA): South-South cooperation and the paradox of regional leadership. Global Governance 17(4), 507-28.

Voeten E (2000) Clashes in the assembly. International Organization 54(2), 185-215.

(2004) Resisting the lonely superpower: responses of states in the United Nations to U.S. Dominance. The Journal of Politics 66(3), 729-54.

(2012) Data and Analyses of Voting in the UN General Assembly. Available at http://papers.ssrn.com/abstract=2111149 .

Volgy, TJ, Derrick VF, Ingersoll RJ. 2003. Preference similarities and group hegemony: G7 voting cohesion in the UN General Assembly. Journal of International Relations and Development 6(1), 51-70.

Volgy TJ, Corbetta R, Grant KA, Baird RG (2011) Major Powers and the Quest for Status in International Politics: Global and Regional Perspectives. London: Palgrave Macmillan.

Wade RH (2011) Emerging world order? From multipolarity to multilateralism in the G20, the World Bank, and the IMF. Politics \& Society 39(3), 347-378.

Walt SM (2006) Taming American Power: Global Responses to U.S. Primacy. New York: W. W. Norton.

Ward S (2017) Status and the Challenge of Rising Powers. Cambridge: Cambridge University Press. 
Wilson D and Purushothaman R (2003) Dreaming with BRICs: The Path to 2050. Goldman Sachs Global Economics Paper 99.

Wohlforth WC (1999) The stability of a unipolar world. International Security 24(1), 541.

Zangl, B, Heußner, F, Kruck, A, Lanzendörfer, X (2016) Imperfect adaptation: how the WTO and the IMF adjust to shifting power distributions among their members. Review of International Organizations 11, 171-196. 